Article

\title{
Net Interoffice Accounts of Global Banks: The Role of Domestic Funding
}

\section{Carmela D'Avino}

School of Business and Law, University of East London, Water Lane, London E15 4LZ, UK; E-Mail: c.davino@uel.ac.uk; Tel.: +44-020-8223-2647

Academic Editor: Nicholas Apergis

Received: 20 February 2015 / Accepted: 12 June 2015 / Published: 26 June 2015

\begin{abstract}
Existing literature has identified domestic restrictive monetary policy and deteriorating funding conditions as the predominant factors explaining the increase in net interoffice accounts of global banks, that is, the net liabilities of parent offices due to their related foreign offices. The purpose of this research is twofold. Firstly, it quantifies the responsiveness of net interoffice accounts to variations in different types of domestic funding. Secondly, the paper assesses whether the relationship between net interoffice accounts and domestic policy-steered rates depends on cross-sectional differences in the funding structure of global banks. Using US banks' balance sheets data collected by the Federal Financial Institutions Examination Council, the results highlight the importance of domestic repo borrowings in explaining net interoffice accounts, especially for larger banks during the crisis. On the other hand, a negative relationship between policy rates and net interoffice accounts is observed only for those global banks with a relatively higher share of repo borrowings.
\end{abstract}

Keywords: US global banks; bank funding; monetary policy; repurchase agreements; panel data

JEL Classification: F33; F34; F42; G21

\section{Introduction}

The current dimension of international banking has no historical precedents. The great majority of large modern banking groups have an institutional structure that goes beyond national borders: global 
banks hold more than $\$ 10$ trillion assets through their foreign-related offices. The drivers of banking internationalization, through the establishment of affiliates, branches, and/or subsidiaries abroad ${ }^{1}$, have changed considerably over the years, especially since the 1970s. Before the collapse of the Bretton Woods system, the growth in international banking activities was primarily driven by the need to support colonial expansion and to facilitate and finance trade and investments abroad [1]. Also, the opening-up of foreign facilities could allow banks to take advantage of more favorable foreign regulations and taxes, expand their activities by attracting local customers, and foster capital flows from high to low-savings countries.

In the last 30 years, banking internationalization has been greatly affected by financial liberalization, which has enabled foreign offices to engage in varied and more complex operations on behalf of the parent bank, such as currency carry trade activities [2-4] and the settlement of currency positions in the FX markets [5]. Also, foreign offices have allowed banks to hold a more diversified and less volatile portfolio on a consolidated basis [6-9].

More recently, the possibility of exploiting an internal capital market has been found to be an additional advantage enjoyed by global banks. De Haas and Lelyveld [10] show that parent offices reallocate capital among foreign subsidiaries depending on the phase of their business cycles, stimulating, in this way, cross-border contagion of shocks. Subsidiaries are found to react to balance sheet expansions of related institutions of the same banking group located elsewhere by enhancing their credit supply in the host country. However, during the latest financial crisis, De Haas and Lelyveld [11] find that subsidiaries have been affected by the financial instability experienced at the group-level and internal capital markets have been used by parents to import liquidity from subsidiaries.

Parent offices themselves can also benefit from borrowing through internal capital markets, as this allows them to cushion against domestic adverse monetary policy or funding shocks. Cetorelli and Goldberg [12] show that US parent offices increase their net liabilities due to their related foreign offices in response to negative monetary policy shocks, impairing the effectiveness of the domestic bank lending transmission channel. Cetorelli and Goldberg [13] have further showed that, during the latest crisis, US-located offices have resorted to borrowing from internal capital markets in order to avoid considerable deleveraging when hit by funding shocks.

It is only recently that net interoffice accounts have attracted notable attention, especially in those studies aimed at assessing cross-border contagion (such as [14] and [15]) and global imbalances [16]. This measure was formally used by Hattori and Shin [3] to understand the scale of carry trade activities of foreign banks located in Japan, especially during the years in which the Bank of Japan engaged in quantitative easing (2001-2006). More recently, [17] have also looked at net interoffice positions of global banks when investigating the behavior of foreign banks located in the US during the dollar funding crisis in 2009.

The purpose of this paper is twofold. Firstly, it aims to investigate the sensitivity of net interoffice accounts to different types of domestic funding, i.e., obtained through repurchase agreements, interbank markets, and private sector deposits. In this regard, this research represents a first attempt to link net interoffice accounts to disentangled sources of domestic funding. Cetorelli and Goldberg [12] find significant responses of global banks' borrowings from internal capital markets to funding shocks;

\footnotetext{
Unless otherwise mentioned, throughout this paper these three entities are defined collectively as "foreign offices."
} 
however, they aggregate all banks' liabilities due to both domestic and foreign sectors. De Haas and Lelyveld [11] have looked at different sources of funding, such as wholesale debt; however, they investigated their effect on lending of parent and foreign offices rather than on net interoffice accounts. Understanding which type of domestic funding dry-up might induce global banks to increase their borrowings from related offices can help to better predict the extent of the cross-border propagation of shocks.

Secondly, this paper explores whether cross-sectional differences in funding through repurchase agreements of global banks result in heterogeneous responses of net interoffice positions to domestic monetary policy. This analysis is motivated by the intention to clarify the puzzling behavior of US banks' net interoffice accounts observed during the latest crisis. Indeed, previous findings suggest that net interoffice accounts fall during a period of monetary expansion; they reached their historical high of $\$ 583$ billion in the last quarter of 2008 , in the same quarter in which total borrowings of depositary institutions from the Federal Reserve reached the unprecedented level of $\$ 667$ billion and the effective federal funds rate stood at only $0.2 \%$. As showed by Cetorelli and Goldberg [13], during the crisis US global banks have increased their net interoffice debt because of deteriorating domestic credit conditions. It is, however, of interest to understand whether, as a general result, the funding structure of global banks should be taken into account when considering the responsiveness of global banks to monetary policy stances. Global banks that rely more on wholesale funding, for instance, might adjust their borrowings via internal capital markets according to the extent of liquidity in domestic non-deposit credit sources. An increase in the policy-steered rate, featured by inflating asset prices, might, indeed, lead those global banks with a high share of secured funding to borrow less from their internal capital markets. This would result in a negative relationship between the federal funds rate and net interoffice borrowings.

The two aims of the paper are pursued with the estimation of a two-step Generalized Methods of Moments dynamic regression [18] and [19] and a Panel Threshold Regression Model [20] respectively. Both empirical approaches use bank-level balance sheet information contained in the quarterly Consolidated Report of Condition and Income (Call report) collected from the Federal Deposit and Insurance Corporation (FDIC) database (https://www2.fdic.gov/call_tfr_rpts/).

The results show that net interoffice accounts increase when global banks reduce their borrowings from both the private sector (via sight deposits) and repo markets. This effect is more pronounced during the period 2007-2010 and for the largest 15 global banks. As expected, the effect of the federal funds rate on net interoffice accounts ceases to be significant during the crisis. In the second part of the empirical analysis it is found that an increase in the policy rate causes net interoffice accounts to increase for those banks that have a low repo funding-to-assets ratio. On the other hand, an increase in the policy rate causes net interoffice accounts to fall for those banks that have a high repo funding-to-assets ratio. These results point to a tight relationship between net interoffice accounts and collateral values: those global banks that have a relatively higher share of repo borrow more from their foreign counterparts whenever their collateral value deteriorates and financing via collateralised markets becomes more costly.

The article is organized as follows. Section 2 proposes a number of stylized facts that support the following empirical analyses and reports two sets of regression estimates. First, it presents the estimates of a dynamic panel regression in which net interoffice accounts are explained primarily by 
US global banks' balance sheets' funding variables. Second, it reports the estimates of a threshold model aimed at assessing whether cross-sectional variations in funding structure result in different behavior of global banks vis-à-vis domestic monetary policy. Section 3 concludes.

\section{Data Analysis and Model Estimations}

\subsection{Stylized Facts on Net Interoffice Accounts in the US}

In the US globalization is a predominant feature of the banking sector: 17 of the 20 largest banks had foreign-related offices in 2007. Foreign operations of US banks are mostly conducted by their branches, which are domestically regulated and report on a quarterly basis to the Federal Financial Institutions Examination Council (FFIEC, form 030, US). Among all non-resident counterparties, foreign-related offices are the largest lenders to US financial institutions: in 2011 over 50\% of gross foreign-held debt was due to own foreign offices. In net terms, domestically-located offices of US global banks are net borrowers to their foreign offices. As shown in Figure 1, net interoffice accounts, equal to the difference between interoffice liabilities and interoffice assets, are made up mainly of interoffice liabilities, while interoffice assets have historically been relatively low.

The biggest increase in interoffice liabilities of US banks was over the period 2002 to 2008, up by $550 \%$. There are a number of possible factors that could potentially explain this trend: restrictive domestic monetary policy, carry trade activities, unsynchronized business cycles, and domestic funding conditions. However, a closer look at the stylized facts suggests that funding availability of US banks has been the most prominent factor in explaining the sustained increase in interoffice liabilities. First, the global dimension of the latest crisis weakens the hypothesis of capital re-allocation among offices located in countries experiencing different phases of the business cycle [10]. Europe and the UK, the two non-offshore foreign banking systems to which US banks have the largest inter-office debts, for instance, were experiencing economic downturns as well. ${ }^{2}$ Second, the carry trades explanation [3] could not justify this increase either, given that worldwide interbank interest rates have been converging and exchange rate volatilities increasing, resulting in large FX position unwinds [21]. Policy interest rate differentials vis-à-vis the euro area and the UK, for instance, have remained positive or null during the whole crisis. Third, interoffice liabilities could not have been stimulated by a restrictive domestic monetary policy: from late 2007 they have kept rising despite the rapid and drastic cut in the federal funds rate and several emergency liquidity injections by the Fed. Figure 2 below shows the evolution of interoffice liabilities in relation to the federal funds rate: over the great moderation period, characterized by low interest rates and steady credit expansion, the growth in interoffice liabilities was rather contained. In late 2004, however, interoffice liabilities started to escalate following the gradual rise in the federal funds rate. This evidence is in line with the argument that when domestic monetary policy is tighter, liquidity flows from foreign-related offices to parents are higher [12]. However, the crisis period has shown a reversal in the relationship between these two series: interoffice liabilities have kept on increasing, notwithstanding the low levels of the federal funds rate.

The majority of interoffice liabilities of US banks are owed to offices located in off-shore centres. Thus, the exact location from which the debt originates cannot be exactly established (see [2]). 

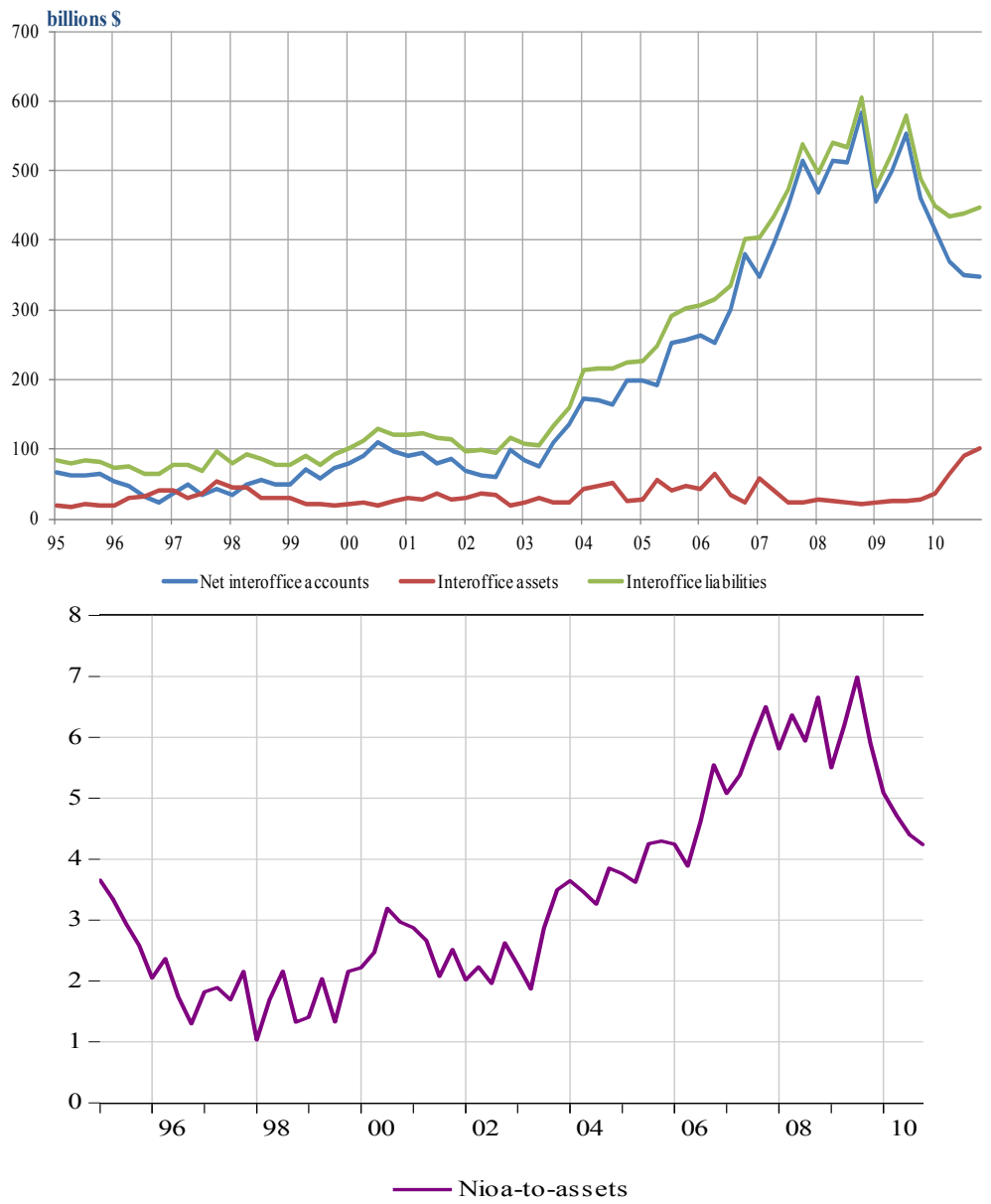

Figure 1. Net interoffice accounts of US global banks. (Source: Federal Reserve Board and Call Report. Note: Net Interoffice Accounts have been computed by the author as the difference between interoffice liabilities and interoffice assets.)

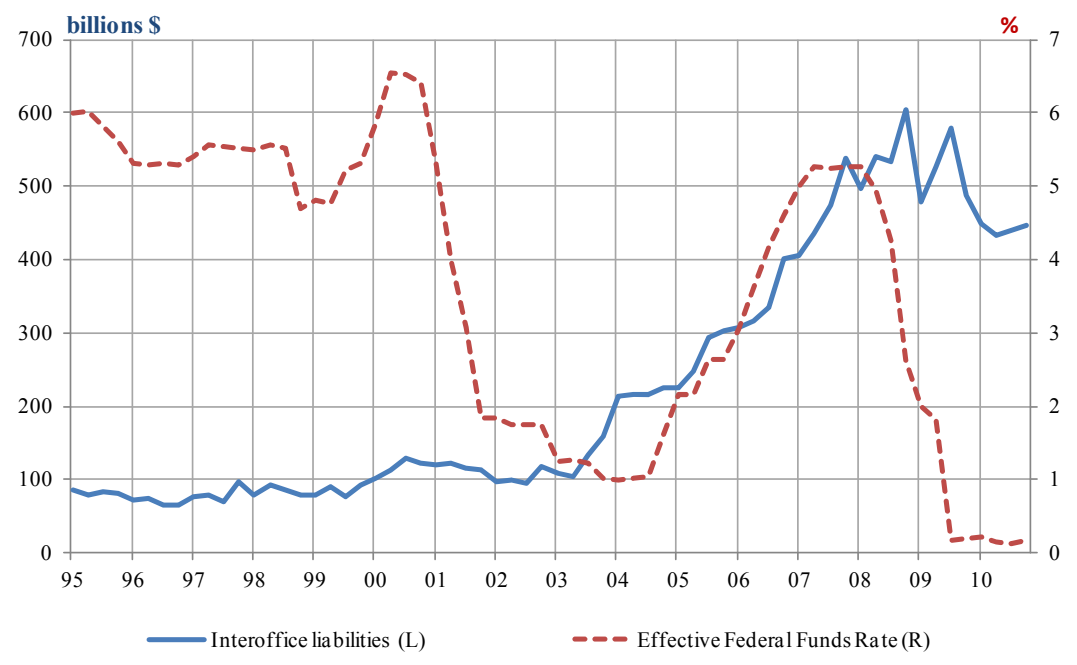

Figure 2. Interoffice liabilities and the Federal Funds Rate. Source: Federal Reserve Board and Call Report.

The disconnection between interoffice liabilities and policy interest rates during the crisis can be attributed to disruptions in funding markets. The level of the federal funds rate, indeed, does not yield 
adequate information on the ease of obtaining funding from sources other than the central bank. In particular, during the crisis, the Fed's non-conventional interventions, i.e., in the form of considerable liquidity injections, pushed the federal funds rate to historically low levels while funding from other sources was disrupted. Falling asset prices and difficulties in pricing some illiquid securities held on the banks' balance sheets had, indeed, notable consequences on both secured and unsecured borrowings.

The tensions in the unsecured credit markets, particularly in interbank markets, since the outburst of the subprime crisis were mainly generated by the increase in counterparty risk, which resulted in rising margin requirements and widening of Libor-OIS spreads [22]. As shown in Figure 3a below, when unsecured funding illiquidity resulted in considerable spikes in the Libor and Libor-OIS spreads, changes in interoffice liabilities have followed a similar path to that of those spreads. Indeed, the peak of the interoffice liabilities in 2008 coincided exactly with the historically high level of the LIBOR-OIS spread, which reached over $3.5 \%$ in the last quarter of 2008. Interoffice liabilities started to decrease only in the second quarter of 2009 when the Libor-OIS spread in the US returned to levels below $1 \%$.

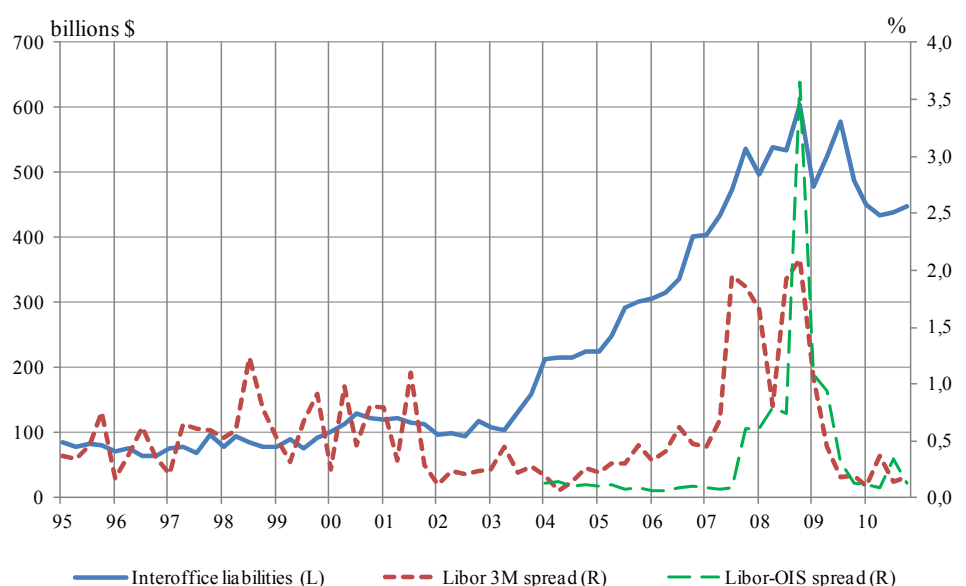

(a)

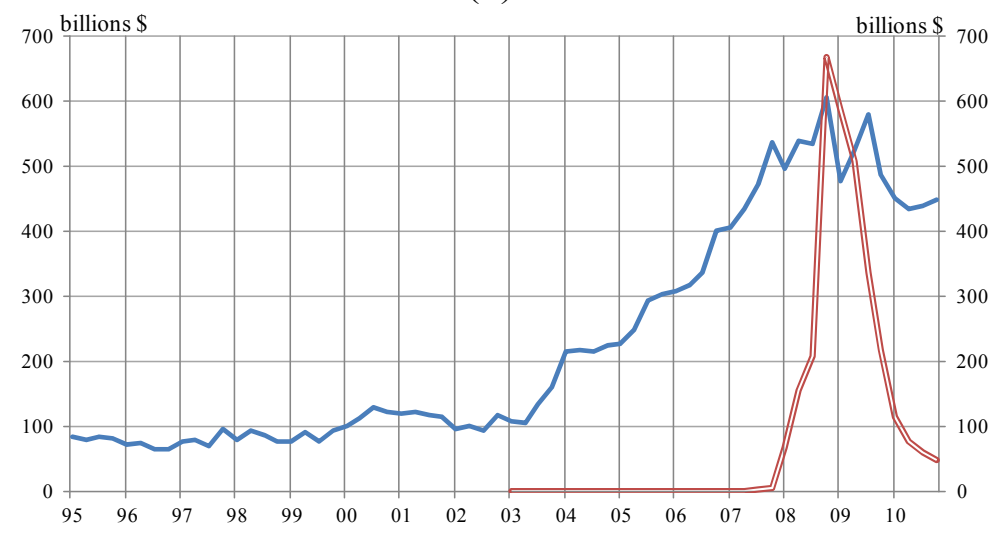

- Interoffice liabilities

(b)

Figure 3. Interoffice liabilities and the Libor and 3M Libor-OIS spreads (a) and borrowings from the FED (b). Source: Federal Reserve Board, Datastream and Call Report.

Figure $3 b$ shows that the relatively large decline in interoffice liabilities at the beginning of 2009, i.e., the first time since the beginning of the crisis, also coincided with the introduction of the Term 
Asset-Backed Securities Loan Facility (TALF) program. With the TALF, conditions in funding markets started to ease as banks were granted additional funds of $\$ 1$ trillion, together with the possibility of borrowing from the Fed by using a much wider class of collateral (including mortgage-backed ABSs). Borrowing through repurchase agreements, which constitute a prominent source of funding for US banks, were also severely hit by the turmoil as activity in repo markets dried up and repo transactions were limited to those involving very short-term maturities and highest-quality collateral. As can be seen in Figure 4 below, until late 2006, interoffice liabilities and securities sold under agreements to repurchase (levels) were moving at a similar pace. Afterwards, repo borrowings by US global banks have slowed down, keeping steady at about $\$ 300$ billion until sample-end while net interoffice liabilities have kept on increasing. In particular, since 2006 the quarterly growth rates of the two series have moved in opposite directions, suggesting a certain degree of substitution between the two funding sources.

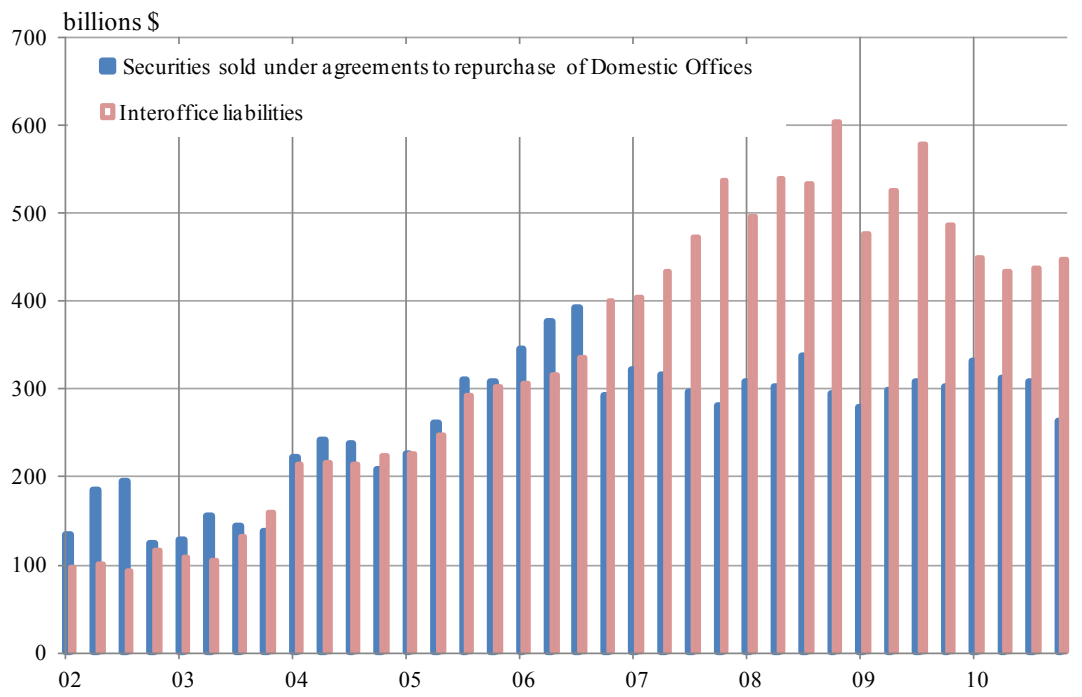

(a)

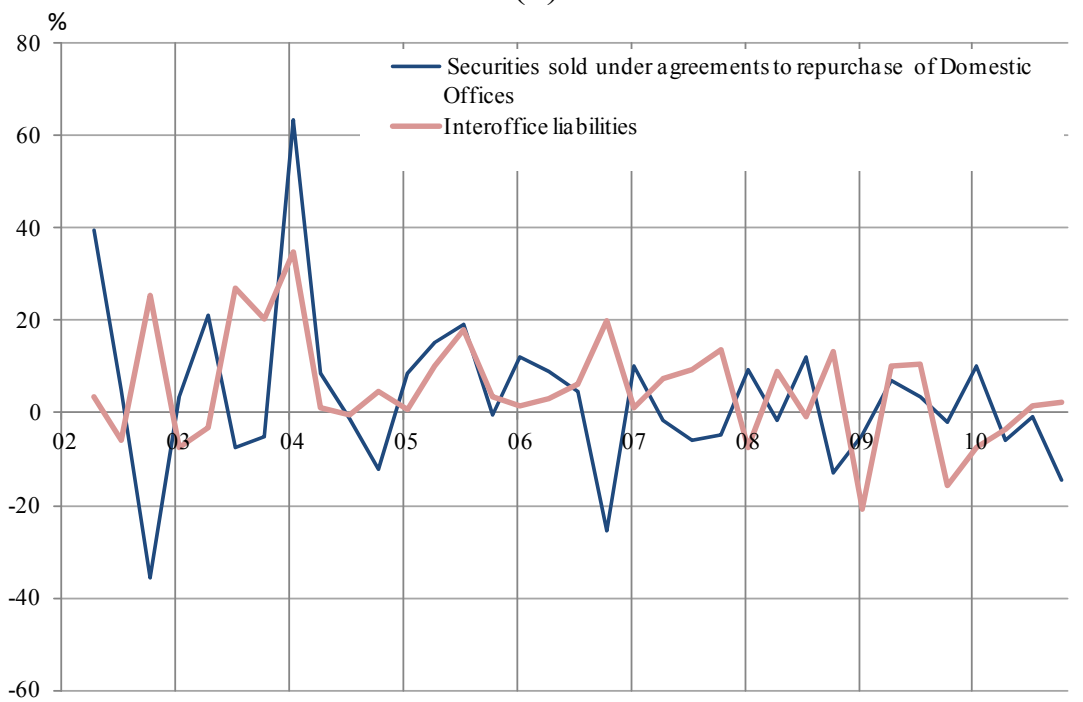

(b)

Figure 4. Interoffice liabilities and securities sold under agreements to repurchase: (a) levels; (b) quarterly growth rates. Source: Call Report. 


\subsection{Empirical Investigation}

\subsubsection{Variables and Sample}

The econometric analysis presented in this paper is centered on several bank-level variables available from the quarterly Report of Condition and Income, or Call Report, collected by the Federal Financial Institutions Examination Council (FFIEC).

A bank is defined as global whenever it has non-zero values of net due tolfrom own foreign offices, Edge and Agreement subsidiaries, and IBFs (Schedule RC- ${ }^{3}$ ) at some point of the chosen sample. The dependent variable is Net Interoffice Accounts, nioa, which is constructed as the difference between "due to" and "due from" own foreign offices, Edge and Agreement subsidiaries, and IBFs so that it takes on a positive (negative) value whenever parent offices are net borrowers (lenders) vis-à-vis their foreign offices.

The descriptive statistics of nioa reported in Table 1 show that despite the fact that in 15 years the number of US global banks has almost halved (201 in 1995 vs. 113 in 2010), aggregated net borrowings owed to foreign offices have more than tripled from 2002 to sample-end. In 2008 nioa reached its historical high of $\$ 583$ billion; in the two following years it diminished slightly but still remained higher than the levels observed before 2006. There is large cross-sectional variation in nioa, as can be noticed from the very low values of mean and median and very large minimum and maximum values, more marked towards the end of the sample.

Table 1. Descriptive Statistics for net interoffice accounts (NIOA), \$Bn.

\begin{tabular}{cccccccc}
\hline Year & Sum & Mean & Median & Min & Max & Std. Dev. & Obs. \\
\hline 1995 & 63.1 & 0.3 & 0.0 & -6.0 & 8.9 & 1.2 & 201 \\
1996 & 23.0 & 0.1 & 0.0 & -16.5 & 7.1 & 1.6 & 188 \\
1997 & 43.6 & 0.3 & 0.0 & -12.5 & 11.5 & 2.3 & 152 \\
1998 & 62.0 & 0.5 & 0.0 & -4.2 & 8.1 & 1.5 & 134 \\
1999 & 81.5 & 0.6 & 0.0 & -3.0 & 11.9 & 1.8 & 131 \\
2000 & 110.4 & 0.9 & 0.0 & -3.4 & 20.7 & 2.7 & 128 \\
2001 & 96.0 & 0.8 & 0.0 & -3.7 & 18.8 & 2.8 & 122 \\
2002 & 99.1 & 0.9 & 0.0 & -7.4 & 21.2 & 3.0 & 116 \\
2003 & 140.4 & 1.3 & 0.0 & -7.4 & 16.3 & 3.6 & 111 \\
2004 & 197.9 & 1.8 & 0.0 & -9.0 & 48.4 & 6.4 & 107 \\
2005 & 255.4 & 2.1 & 0.0 & -30.2 & 65.1 & 8.5 & 124 \\
2006 & 378.4 & 3.3 & 0.1 & -8.2 & 81.0 & 11.7 & 115 \\
2007 & 513.0 & 4.4 & 0.1 & -12.1 & 87.7 & 14.6 & 117 \\
2008 & 583.0 & 5.0 & 0.1 & -10.8 & 116.5 & 18.5 & 117 \\
2009 & 459.6 & 4.0 & 0.1 & -13.1 & 103.5 & 14.0 & 116 \\
2010 & 346.9 & 3.1 & 0.1 & -73.2 & 111.6 & 16.3 & 113 \\
\hline
\end{tabular}

Source: Call report. Notes: Net interoffice accounts refer to the FDIC series "Net due to own foreign offices, Edge and Agreement subsidiaries and IBFs" (ffiec code rcon2941) minus "Net due from own foreign offices, Edge and Agreement subsidiaries and IBFs" (ffiec code rcon2163). Figures relate to amounts reported in the fourth quarter of the corresponding year.

\footnotetext{
In particular, banks with foreign offices complete the FFIEC 031 reporting form, containing the Schedule RC-H.
} 
As shown in Table 2, the larger the global bank (i.e., in terms of total assets) the more it borrows in net terms from its foreign offices; in particular, in $200870 \%$ of nioa was due from the six largest banks with total assets of more than $\$ 200$ billion. The bottom of Table 2 shows the nioa-to-assets ratio by bank size in order to gauge the relative importance of nioa in financing assets. The six largest global banks have a positive nioa, which depicts a relatively contained variability around the mean: between $2 \%$ and $14 \%$ of assets are financed by nioa. Medium-sized banks, on the other hand, have an average nioa-to-assets ratio equal to 0.073 but the degree of heterogeneity is more important. For some banks, nioa are a very important source of funding, financing up to $31 \%$ of assets. Medium-sized banks do not depict large net outflows to their related offices: the largest negative nioa is equal to only 0.08. Small banks, on the other hand, have the highest heterogeneity in terms of relative importance in nioa as a source of funding: while on average only 5.5\% of assets are financed by nioa, this source of funding can be extremely important for some banks, going up to $80 \%$ of total assets. Among all global banks, small banks depict important net lending to their foreign related offices via their internal capital markets: their largest negative nioa is equal to 0.44 .

Table 2. Nioa and bank size as of the first quarter of 2008 .

\begin{tabular}{lccc}
\hline Total Assets Range (\$bn) & Nioa & Number of Banks & \% of Total \\
\hline$>200$ & 304 & 6 & 70 \\
$>100$ and $\leq 200$ & 78 & 7 & 18 \\
$\leq 100$ & 54 & 60 & 12 \\
\hline \multicolumn{3}{c}{ Nioa-to-Assets } \\
\hline Total Assets Range (\$bn) & Mean & Max. & Min. \\
$>200$ & 0.064 & 0.14 & 0.02 \\
$>100$ and $\leq 200$ & 0.073 & 0.31 & -0.08 \\
$\leq 100$ & 0.055 & 0.80 & -0.44 \\
\hline
\end{tabular}

Source: Author's calculation based on data from FFIEC.

The quarterly unbalanced panel considered in the estimation contains 102 global banks over the period 1995 to 2010; the banks included in the sample are those for which at least seven years of consecutive data points of nioa are available.

The bank-level balance sheet variables considered primarily capture the ease of obtaining funding from a variety of channels. Funding of domestic offices is broken down into borrowings in the form of domestic inter-bank debt, private sector deposits, and repurchase agreements. The former two types of funding are further classified into demand and term deposits. Funding availability at foreign offices is proxied by total deposits. The effective federal funds rate is used to keep close track of the central bank's steered policy rate. A number of macroeconomic variables were initially incorporated to the analysis to capture other possible determinants of nioa, such as interest rate differentials, exchange rates, and real GDP, but they were not found to significantly explain changes in nioa over the sample considered. Details and summary statistics on all the variables kept in the analysis are reported in Table 3.

Total deposits held by foreign offices have expanded greatly over the years, reflecting the growing importance of banking globalization: they quadrupled over the period 2001-2009 reaching \$1.3 trillion. Funding obtained by domestic offices from domestic markets comes mainly from transaction deposits of the private sector ( $\$ 383$ billion in 2009) and securities sold under repo agreements ( $\$ 256$ billion in 
2009). Funding though interbank deposits has increased notably over the years, reaching a total of almost $\$ 50$ billion in 2009 (transactional and non-transactional confounded).

Table 3. Summary statistics and source of other balance-sheet variables, $\$ B n$.

\begin{tabular}{|c|c|c|c|c|}
\hline Total & & Source & Code & Availability \\
\hline & Total deposits at foreign offices & Call Report & refn2200 & $1995-2010$ \\
\hline 1995 & 226.89 & & & \\
\hline 2001 & 469.36 & & & \\
\hline \multirow[t]{2}{*}{2009} & 1301.43 & & & \\
\hline & $\begin{array}{l}\text { Non-transaction deposits at domestic offices } \\
\text { of the private sector }\end{array}$ & Call Report & $\operatorname{rcon} 2385$ & $1995-2010$ \\
\hline 1995 & 0.08 & & & \\
\hline 2001 & 1.52 & & & \\
\hline \multirow[t]{2}{*}{2009} & 10.52 & & & \\
\hline & $\begin{array}{l}\text { Transaction deposits at domestic offices of } \\
\text { the private sector }\end{array}$ & Call Report & $\operatorname{rcon} 2215$ & $1995-2010$ \\
\hline 1995 & 129.52 & & & \\
\hline 2001 & 250.12 & & & \\
\hline \multirow[t]{2}{*}{2009} & 383.00 & & & \\
\hline & $\begin{array}{c}\text { Interbank non-transaction deposits at } \\
\text { domestic offices }\end{array}$ & Call Report & rconb552 & $2001-2010$ \\
\hline 1995 & - & & & \\
\hline 2001 & 5.04 & & & \\
\hline \multirow[t]{2}{*}{2009} & 22.67 & & & \\
\hline & $\begin{array}{c}\text { Interbank transaction deposits at } \\
\text { domestic offices }\end{array}$ & Call Report & rconb551 & $2001-2010$ \\
\hline 1995 & - & & & \\
\hline 2001 & 17.28 & & & \\
\hline 2009 & 25.06 & & & \\
\hline & $\begin{array}{l}\text { Securities sold under agreements to } \\
\text { repurchase at domestic offices }{ }^{(*)}\end{array}$ & Call Report & rconb995 & $2002-2010$ \\
\hline 1995 & - & & & \\
\hline 2001 & 128.20 & & & \\
\hline 2009 & 255.96 & & & \\
\hline
\end{tabular}

${ }^{(*)}$ Figures for 2001 refer to those of the first quarter 2002.

\subsubsection{Model Estimation I}

The inference is based on the following autoregressive-distributed lag model:

$$
\text { nioa }_{i, t}=\beta_{j} \text { nioa }_{i, t-1}+\mu_{p} \operatorname{dep}_{i, t}^{F}+\kappa r_{i, t}+\Phi_{i, t}^{\prime} \lambda+\alpha_{i}+v_{i t},
$$

where $i$ is the index for each bank such that $i=1, \ldots, N$ and $t$ is the time index. The variable nioa represents net interoffice accounts and $d e p_{i, t}^{F}$ are deposits at foreign offices. The vector $\Phi_{i, t}$ mainly contains those variables that refer to different sources of funding available to domestic offices: demand 
and term deposits of both the private sector and domestic banks and collateralized borrowings (i.e., under repurchase agreements). $r_{i, t}$ is the federal funds rate and $\alpha_{i}$ is the unobserved bank-specific effect.

Judson and Owen [18] suggest that in a dynamic setting with an unbalanced panel and a small time sample, the Generalized Method of Moments (GMM) is the most suitable framework for estimating asymptotically efficient estimators. Here the Arellano-Bover/Blundell-Bond two-steps estimator [19] has been employed in order to overcome the weak instrument problem that might arise when the dependent variable is highly persistent and/or the ratio of the variance associated to the fixed effect to the variance of the idiosyncratic error is too large. The standard errors are corrected for heteroskedasticity and serial correlation and the Sargan test is carried out in order to test the validity of specification of the estimated model.

The first column of Table 4 reports the GMM estimates of (1) with a limited set of variables (i.e., excluding interbank and repo domestic borrowings), that is, all those series that are available over the whole sample 1995-2010 (see Table 2 for details). The second and third columns report the estimates of (1) over the samples 2002-2010 and 2007-2010, respectively; the former sample is chosen according to the availability of the repo debt and interbank borrowings variables.

Table 4. GMM Estimation, Dependent variable: nioa.

\begin{tabular}{cccc}
\hline Variables & Sample 1995-2010 & Sample 2002-2010 & Sample 2007-2010 \\
\hline nioa $_{t-1}$ & $0.830 * * *(0.000)$ & $0.833 * * *(0.000)$ & $0.259(0.318)$ \\
Foreign deposits & $0.038 * * *(0.000)$ & $0.054 * * *(0.000)$ & $0.420 * *(0.204)$ \\
Federal funds rate & $25323.43 * * *(14.59)$ & $91384 * * *(25.84)$ & $-77270 *(39689)$ \\
Non-transaction deposits & $0.548 * * *(0.000)$ & $0.565 * * *(0.000)$ & $1.679 *(0.860)$ \\
Transaction deposits & $-0.039 * * *(0.000)$ & $-0.161 * * *(0.000)$ & $-0.514 *(0.279)$ \\
Interbank non-transaction deposits & - & $0.640 * * *(0.000)$ & $0.620(0.710)$ \\
Interbank transaction deposits & - & $1.183 * * *(0.000)$ & $0.221(1.706)$ \\
Repo debt & - & $-0.068 * * *(0.000)$ & $-0.554 * * *(0.071)$ \\
Cross-sections included & 102 & 92 & 48 \\
Sargan test $p$-value & 0.566 & 0.737 & 0.939 \\
\hline
\end{tabular}

Notes: Table 4 reports the estimates of a dynamic Generalized Methods of Moments (GMM) regression where Net Inter-Office Accounts (nioa) is the dependent variable. Standard errors and covariance are corrected for heteroskedasticity and serial correlation [23]. Standard errors in parentheses. As in Arellano and Bover [19] and Blundell and Bond [24] the instruments used are the lagged differences (for the level equation) and lagged levels (for the differenced equation). A two-steps estimator is computed and the fixed effect is removed with orthogonal deviations. The Sargan test for over-identifying restriction is distributed according to a $\chi^{2}$ distribution. The crisis dummy takes the value of 1 over the period 2007 quarter 3-2010 quarter 4 and 0 otherwise. ${ }^{* * *}, * *, *$ refer to statistical significance at the $0.001,0.05$, and 0.1 level, respectively.

Availability of deposits available at foreign offices has a positive and significant effect on nioa in each of the three regressions; however, during the crisis, the estimated coefficient of foreign deposits is much larger and equal to 0.420 compared to 0.038 in the overall sample period. This result implies that nioa is positively related to the availability of stable liquidity funding such as deposits available at foreign offices. During the crisis, this relationship is even stronger, reflecting an intensified redistribution of liquidity among banking groups via internal capital markets; this result is similar to the findings by Cetorelli and Goldberg [13]. Moreover, this result supports the possibility of a 
flight-to-safety effect witnessed during the financial crisis; that is, foreign depositors might have switched their deposits away from US branches in favor of domestic banks, triggering a fall in nioa. The effect of the federal funds rate is positive and significant over the whole sample: an increase in the federal funds rate by $1 \%$ increases the average nioa by over $\$ 25$ billion. This result confirms the previous findings that global banks respond to a domestic restrictive monetary policy by importing liquidity via their internal capital market. During the crisis, however, this general result does not hold anymore: the estimated coefficient of the federal funds rate is negative and marginally significant. This result reflects the fact that domestic funding conditions, such as those in repo markets, rather than the monetary policy stance, have been an important driver of nioa, notwithstanding the low level of the federal funds rate. This result is in line with the findings by De Haas and Lelyveld [11] and is further confirmed by the estimated coefficient of repo debt, which is negative and strongly significant in both samples. The estimated coefficient suggests a sizable degree of substitution between funding through repo and internal capital markets, especially during the crisis, when every $\$ 1$ fall in repo debt increased nioa by $\$ 0.56$. Therefore, the reduction of liquidity in repo markets, caused by the deterioration of banks' balance sheets and uncertainty about the fundamental value of some assets, has led global banks to tap this drop in funding by withdrawing funds from their foreign offices.

Transaction deposits are also negatively related to evolution in nioa; its estimated coefficient is four times larger during the crisis than over the sample 2002-2010 even if it is significant at the $10 \%$ level. Lastly, it is interesting to note that the other types of funding-non-transactional deposits and interbank markets - have positive and significant coefficients over the sample 2002-2010. This positive relationship can be explained by the fact that not all changes in funding are replaced by nioa. As found in De Haas and Lelyveld [11], during stable economic conditions internal capital markets are used to redistribute liquidity across the banking group. Therefore, during buoyant economic conditions in which savings are high and interbank markets are functioning correctly, the increase in nioa is due to liquidity redirection through internal capital markets rather than compensating for the loss of a domestic funding source.

Most of the regression estimates of (1) during 2007-2010 are either not significant or become marginally significant. This is probably due to the fact that there are important cross-sectional responses in the way nioa was affected during the crisis. Most notably, it could be argued that the large degree of substitution between repo debt and nioa could be more important for larger banks that rely more on wholesale funding.

Table 5 below replicates the estimation in the last column of Table 4 by bank size over the period 2007-2010. The first column reports the estimates of (1) for the four largest banks, those with average total assets over $\$ 1$ trillion; the second and the last columns report the estimates for the banks with average assets equal to more than and less than $\$ 1$ billion, respectively. For larger banks, the increase in nioa during the crisis was primarily explained by the contraction in funding from repo markets. In the sample of the largest 15 global banks, however, the fall in transaction deposits also significantly affects the increase in nioa. Smaller banks, on the other hand, have significantly increased their net borrowings from their internal capital market, however, not to respond to a particular domestic funding constraint. The increase in nioa for this subset of global banks was motivated by the availability of foreign deposits, implying that the liquidity that was imported was mainly driven by either a precautionary motive or to restore their balance sheet following increasing defaults. Smaller banks 
were not affected as much as large banks by the dry-up in wholesale funding markets; however, they still needed to raise external funds to cover the losses brought about by nonperforming assets. The estimated effect on nioa reflects the increase in uncertainty witnessed in financial markets, translated into the greater difficulty for smaller banks of raising additional unsecured funding.

Table 5. GMM Estimation. Dependent variable: nioa, sample 2007-2010.

\begin{tabular}{cccc}
\hline Variables & Largest 4 Banks & Largest 15 Banks & Other Banks \\
\hline nioa $_{t-1}$ & $0.763 * * *(0.216)$ & $0.716 * * *(0.163)$ & $-0.029(0.082)$ \\
Foreign deposits & $0.110(0.159)$ & $0.140(0.164)$ & $0.857 * * *(0.145)$ \\
Federal funds rate & $1799562(2583567)$ & $-19287(326006)$ & $-25767(11214)$ \\
Non-transaction deposits & $-0.084(1.510)$ & $1.234(0.888)$ & $0.019(0.150)$ \\
Transaction deposits & $-0.313(0.286)$ & $-0.376 * *(0.156)$ & $0.223(0.183)$ \\
Interbank non-transaction deposits & $0.525(0.659)$ & $0.456(0.482)$ & $0.686(0.862)$ \\
Interbank transaction deposits & $-0.326(2.236)$ & $-0.220(1.683)$ & $-0.848(0.851)$ \\
Repo debt & $-0.400 * * *(0.093)$ & $-0.432 * * *(0.041)$ & $-0.113(0.128)$ \\
Cross-sections included & 4 & 15 & 63 \\
Sargan test $p$-value & 0.565 & 0.206 & 0.649 \\
\hline
\end{tabular}

Notes: Table 5 reports the estimates of a dynamic Generalized Methods of Moments (GMM) regression where Net Inter-Office Accounts (nioa) is the dependent variable. Standard errors in parentheses. Banks are ranked by their asset size and then classified as the largest four (assets on average greater than $\$ 1$ trillion), the largest 15 (assets on average greater than $\$ 100$ billion), or other banks (assets on average less than $\$ 100$ billion). Standard errors and covariance are corrected for heteroskedasticity and serial correlation [23]. As in Arellano and Bover [19] and Blundell and Bond [24] the instruments used are the lagged differences (for the level equation) and lagged levels (for the differenced equation). A two-steps estimator is computed and the fixed effect is removed with orthogonal deviations. The Sargan test for over-identifying restriction is distributed according to a $\chi^{2}$ distribution. The crisis dummy takes the value of 1 over the period 2007 quarter 3-2010 quarter 4 and 0 otherwise. ${ }^{* * *},{ }^{* *},{ }^{*}$ refer to statistical significance at the $0.001,0.05$, and 0.1 level, respectively.

\subsubsection{Model Estimation II}

In the previous sub-section it has been argued that domestic funding conditions can be important determinants of nioa. Estimates from Table 4 point to the existence of a non-linear effect of the federal funds rate on nioa, while in Table 5 it has been shown that during the crisis the monetary policy rate does not significantly explain nioa. This section aims at shedding some light on whether the impact of the federal funds rate on nioa varies across banks depending on their funding structure rather than on their size. There is, indeed, still a large heterogeneity of banks in the group of small banks, some of which are also highly reliant on wholesale funding. Most notably, the focus will be here on funding through securities sold under repo agreements, which constitutes for many global banks an important source of funding, and, as shown in Table 4, has a negative and strongly significant effect on nioa. However, there are important cross-sectional differences in the ratios of repo funding-to-total assets in the considered sample of global banks, which can vary between 0 and 0.5 .

Therefore, it might be interesting to investigate whether when the central bank reduces its steered rates to stimulate interbank borrowing and lending during a banking crisis, collateral deterioration 
leads those global banks that finance a greater share of their assets through repo markets to rely relatively more on interoffice borrowings.

A Panel Threshold Regression Model (PTRM), as proposed by [20], is used to test whether the effect of policy rates on nioa differs when accounting for cross-sectional variations in funding through repo markets of global banks. The variables are divided by total assets as the focus here is on the relative importance of repo in a bank's funding structure.

The PTRM estimated has the following form:

$$
\left(\frac{\text { nioa }}{a}\right)_{i t}=\mu_{i}+\beta_{1}^{\prime} r_{t} I\left(\left(\frac{\text { repo }}{a}\right)_{i t} \leq \gamma\right)+\beta_{2}^{\prime} r_{t} I\left(\left(\frac{r e p o}{a}\right)_{i t}>\gamma\right)+\beta_{3}^{\prime} z_{i t}+\varepsilon_{i t} \text {, }
$$

where $\mathrm{I}()$ is an indicator function, $a_{i t}$ stands for total assets of bank $i$ at time $t, r_{t}$ is the effective federal funds rate at time $t$, and repo $o_{i t}$ are securities sold under agreements to repurchase at domestic offices of bank $i$ at time $t$. The vector $z_{i t}$ contains regime-independent variables such as the ratio of foreign deposits-to-total assets as well as additional regressors to reduce the possibility of spurious correlations. ${ }^{4} \varepsilon_{i t}$ is the vector of disturbances of bank $i$ at time $t$ and $\gamma$ is the threshold of the variable securities sold under agreements to repurchase-to-total assets. Specification (2) allows the coefficient of $r_{t}$ to depend on a threshold variable, which is the ratio of repo funding-to-total assets. Table 5 shows the regression slope estimates of (2) and the estimated threshold, $\gamma$, for the balanced quarterly panel over the period 2002 to 2010, which includes 51 global banks. The estimated coefficient of $r_{t} I\left(\left(\frac{r e p o}{a}\right)_{i t} \leq \gamma\right)$ is positive and significant at the $5 \%$ significance level, equal to 0.12 . This result suggests that those banks that finance their assets with a lower share of borrowings through repo agreements, equal to $20 \%$ or less of their total assets (as found by the estimate of the threshold at the bottom of Table 6), adjust their nioa in the same direction of federal funds rates. For this kind of bank, then, the general result found in [12] holds: a loosening in domestic monetary policy results in a reduction in net borrowings of domestic banks from their foreign affiliates. The estimated coefficient of $r_{t} I\left(\left(\frac{r e p o}{a}\right)_{i t}>\gamma\right)$, on the other hand, is negative and significant at the $5 \%$ significance level, equal to -0.35 . That is, banks that finance more than $20 \%$ of their assets with borrowing through repo agreements react differently to a change in domestic policy rate: a fall in federal funds rate results in an increase in nioa.

This set of results confirms the prediction that those global banks that finance a greater share of their assets through repo markets borrow more from their foreign affiliates when their collateral deteriorates during a banking crisis. The negative and significant effect of federal funds rates on nioa for those banks can be explained as follows. The slow increase in the federal funds rate from 2003 happened in conjunction with inflating asset prices, which enhanced the value of banks' collateral. During this period, those global banks that were greatly reliant on borrowing from repo markets had strong collateral and borrowing from foreign affiliates was diminishing. However, as the federal funds rate started to fall dramatically in 2008 and the banking crisis had deteriorated banks' balance sheets,

4 These regressors include the square and the cube of deposits at foreign offices and repo funding as well as the product of these two variables, as in [20]. 
global banks started borrowing more from their foreign affiliates, given the rising difficulty in borrowing from repo markets. Since regression (2) considers the variables normalized by total assets, the results in Table 5 might be driven entirely by the asset side of the bank balance sheet for high-repo-funded banks, rather than a shift in the nioa. Therefore, for robustness check, Table 7 below reports the two sets of estimates of a linear version of (2) in which the variables are not normalized by assets. The estimates of the first column refer to the sample of global banks with the highest gross amount of repo borrowings; the second column shows the estimates of the model for all other banks. The estimated coefficient of the federal funds rate is significant in both instances and is negative for the sample of banks with the largest amount of outstanding repo debt and positive for all other banks.

Table 6. Panel threshold regression estimation.

\begin{tabular}{lcc}
\hline Dependent variable: $n$ ioa-to-assets & & \\
\hline Regime-dependent variable & Repo financing & Estimate \\
Federal funds rate & low & $0.116^{* *}$ \\
& & {$[0.049]$} \\
Federal funds rate & high & $-0.352^{* *}$ \\
& & {$[0.152]$} \\
\hline Regime-independent variable & Estimate \\
\hline \multirow{2}{*}{ Foreign deposits-to-assets } & $0.640 * * *$ \\
\hline Threshold & {$[0.070]$} \\
\hline$\gamma$ & & 0.202 \\
\hline
\end{tabular}

Notes: The table reports the estimates of a Panel Threshold regression where NIOA-to-assets is the dependent variable. In brackets White standard errors, i.e., corrected for heteroskedasticity and serial correlation [23]. $* * *, * *, *$ refer to statistical significance at the $0.001,0.05$ and 0.1 respectively.

Table 7. Estimation by repo funding. Dependent variable: nioa.

\begin{tabular}{ccc}
\hline Variables & Higher Repo & Lower Repo \\
\hline Foreign deposits & $0.354 * * *(0.056)$ & $0.263 * * *(0.023)$ \\
Federal funds rate & $-8283027 * *(3680297)$ & $1268646 *(668641)$ \\
Cross-sections included & 9 & 95 \\
\hline
\end{tabular}

Notes: Table 7 reports the estimates of a Panel Two-Stages EGLS (cross-section random effect) regression where Net Inter-Office Accounts (nioa) is the dependent variable and the sample period 2002-2010. A constant (unreported) is included in the regressions. Banks are ranked according to their repo borrowings as higher (on average greater than $\$ 1$ billion), and lower repo. Standard errors and covariance are corrected for heteroskedasticity and serial correlation [23]. The instruments used are assets and deposits held at foreign offices (sight and non-transactional. $* * *, * *, *$ refer to statistical significance at the $0.001,0.05$, and 0.1 level, respectively.)

\section{Conclusions}

This paper contributes to further understanding the reasons why US banks borrow from their foreign offices. The first part of the empirical methodology focuses on banks' access to domestic funding, both from secured and unsecured markets, and its role in explaining changes in net interoffice accounts (nioa), that is, the net liabilities of parent banks due to their foreign offices. It is shown that 
variations in domestic sight deposits and securities sold under repurchase agreements significantly affect nioa with a negative sign. Given their highest reliance on wholesale funding, this effect is more pronounced for the sample of large banks. However, the US global banks in the sample considered have a funding structure that varies considerably across institutions. Therefore, the second part of the empirical investigation shows that domestic monetary policy, proxied by the federal funds rate, affects positively and significantly net interoffice accounts only for those global banks whose funding structure entails relatively less borrowing through repo markets. This result suggests that cross-sectional differences in the funding structure of global banks are an important factor to be taken into account when investigating the dynamics of interoffice lending and borrowings.

\section{Acknowledgments}

I would like to thank three anonymous referees as well as Thomas Vieten for discussing this paper at the World Finance Conference (Rio de Janeiro, 2012) and the participants at the International IFABS 2012 Conference (Valencia) and at the 2011 Fourth International DMM (University of Montpellier). Also, I am extremely grateful to Yannis Kalantzis for his discussion at the internal seminar at the Banque de France and to Loriana Pelizzon for the very useful remarks.

\section{Conflicts of Interest}

The author declares no conflict of interest.

\section{References}

1. Darby, M.R. The Internationalization of American Banking and Finance: Structure, Risk, and World Interest Rates. J. Int. Money Financ. 1986, 5, 403-428.

2. Galati, G.; Heath, A.; McGuire, P. Evidence of Carry Trade Activity. BIS Q. Rev. 2007, September, 27-41.

3. Hattori, M.; Shin, H.S. Yen Carry Trade and the Subprime Crisis. IMF Staff Pap. 2009, 384-409.

4. McGuire, P.; von Peter, G. The US Dollar Shortage in Global Banking and the International Policy Response. Available online: http://papers.ssrn.com/sol3/papers.cfm?abstract_id=1491526 (accessed on 27 June 2011).

5. Mullineux, A.W.; Murinde, V. Handbook of International Banking; Edward Elgar Publishing Ltd.: Chelthenham, UK, 2003; pp. 39-42.

6. Markowitz, H. Portfolio Selection. J. Financ. 1952, 7, 77-91.

7. Lewis, K.K. Trying to Explain the Home Bias in Equities and Consumption. J. Econ. Lit. 1999, 37, 571-608.

8. Fratzscher, M.; Imbs, J. Risk Sharing, Finance, and Institutions in International Portfolios. J. Financ. Econ. 2009, 94, 428-447.

9. Schoenmaker, D.; Wagner, W. The Impact of Cross-Border Banking on Financial Stability. Available online: http://papers.tinbergen.nl/11054.pdf (accessed on 7 July 2013).

10. De Haas, R.; van Lelyveld, I. Internal Capital Markets and Lending by Multinational Bank Subsidiaries. J. Financ. Intermed. 2010, 19, 1-25. 
11. De Haas, R.; van Lelyveld, I. Multinational Banks and the Global Financial Crisis: Wheathering the Perfect Storm? J. Money Credit Bank. 2014, 46, 333-364.

12. Cetorelli, N.; Goldberg, L.S. Banking Globalization and Monetary Policy Transmission. J. Financ. 2012, 67, 1811-1843.

13. Cetorelli, N.; Goldberg, L.S. Global Banks and International Shock Transmission: Evidence from the Crisis. Int. Monet. Fund Econ. Rev. 2011, 59, 41-46.

14. Bruno, V.; Shin, H.S. Cross-Border Banking and Global Liquidity. Rev. Econ. Stud. 2014, doi:10.1093/restud/rdu042.

15. Shin, H.S. Global Banking Glut and Loan Risk Premium. IMF Econ. Rev. 2012, 60, 155-192.

16. Gourinchas, P.O. Global Imbalances and Liquidity. In Proceedings of the Asia Economic Policy Conference at the Federal Reserve Bank of San Francisco, San Francisco, CA, USA, 29-30 November 2011.

17. McGuire, P.; von Peter, G. The US Dollar Shortage in Global Banking. Available online: http://www.bis.org/publ/qtrpdf/r_qt0903f.pdf (accessed on 20 May 2015).

18. Judson, R.A.; Owen, A. Estimating Dynamic Panel Data Models: A Practical Guide for Macroeconomists. Econ. Lett. 1999, 65, 9-15.

19. Arellano, M.; Bover, O. Another Look at the Instrumental Variable Estimation of Error-Components Models. J. Econom. 1995, 68, 29-52.

20. Hansen, B.E. Threshold Effects in Non-Dynamic Panels: Estimation, Testing and Inference. J. Econom. 1999, 93, 345-368.

21. Melvin, M.; Taylor, M.P. The Crisis in the Foreign Exchange Market. J. Int. Money Financ. 2009, $28,1317-1330$.

22. Hordahl, P.; King, M.R. Developments in Repo Markets during the Financial Turmoil. Available online: http://www.bis.org/publ/qtrpdf/r_qt0812e.htm (accessed on 20 May 2015).

23. White, H. A Heteroskedasticity-Consistent Covariance Matrix Estimator and a Direct Test for Heteroskedasticity. Econometrica 1984, 48, 817-838.

24. Blundell, R.; Bond, S. Initial conditions and moment restrictions in dynamic panel-data models. J. Econom. 1998, 87, 115-143.

(C) 2015 by the author; licensee MDPI, Basel, Switzerland. This article is an open access article distributed under the terms and conditions of the Creative Commons Attribution license (http://creativecommons.org/licenses/by/4.0/). 